\title{
Isus iz evanđelja i Isus danas
}

Ervin Budiselić

Biblijski institut, Zagreb

ebudiselic@bizg.hr

UDK:27-31:277.4:279.15:141.78

Pregledni članak

Primljeno: 1, 2018.

Prihvaćeno: 2, 2018.

\section{Sažetak}

Započevši navođenjem suvremenih prevladavajućih vrijednosti tolerancije, dijaloga i političke korektnosti, članak analizira Isusov govor i učenja u sinoptičkim evanđeljima u svjetlu navedenih vrijednosti. Prvo, članak analizira Isusov govor o ljubavi, a nakon toga usmjerava se na njegov oštar govor i učenje. Potom, članak analizira reakcije različitih pojedinaca i grupa ljudi na Isusov govor i učenje. Na temelju poduzete analize, u posljednjem dijelu članka uspoređuje se Isus iz sinoptičkih evanđelja s iskrivljenom slikom Isusa koja je ponekad prisutna u suvremenom kršćanstvu. Zaključuje se kako je suvremena zapadna kultura izopačila Isusovu sliku iz evanđelja, stvorivši suvremenog Isusa koji u svojem govoru i učenju odražava današnje prevladavajuće vrijednosti. Međutim, Isus je isti jučer, danas i zauvijek, i trebamo biti pažljivi da ne slijedimo nekakvog suvremenog Isusa, već onoga iz evandelja.

Ključne riječi: Isus iz evanđelja, moderni Isus, postmodernizam, politička korektnost, Božja ljubav, grijeh, oštar govor i učenje

\section{Uvod}

U vremenu tolerancije, dijaloga i političke korektnosti u današnjoj zapadnoj kulturi, snažan naglasak stavlja se na iskazivanje časti i poštovanja prema onima koji razmišljaju, vjeruju ili tvrde drukčije. U skladu s učenjem postmodernizma, svatko ima pravo glasa i svačije se mišljenje treba uvažiti. Nema univerzalne istine, a svačije je mišljenje jednako vrijedno. Možemo izraziti svoje uvjerenje, ali pritom 
nije preporučljivo osuđivati druge ili njihova razmišljanja proglasiti pogrešnima, lažnima, ponižavajućima ili opasnima. Čak i među evanđeoskim kršćanima, koji tradicionalno podržavaju Bibliju kao jedini nepogrešivi autoritet vjere i života, prisutna je sve izrazitija tendencija suzdržavanja od govorenja istine u ljubavi, koja biva zamijenjena govorom o „dijalogu“, „toleranciji“ $i$,neosuđivanju“, ili pak stavom „tko si ti da sudiš drugima“. Sve smo bliže situaciji u kojoj se ljubav odvaja od istine, tako da se oni koji „govore istinu u ljubavi“ nazivaju ljudima „bez ljubavi“, a oni koji nude „ljubav bez istine“ uživaju pohvale, kao primjeri kršćanske ljubavi.

Ako se okrenemo stranicama Novoga zavjeta, osobito sinoptičkih evanđelja, susrećemo Isusa koji se svojim stilom govorenja i ponašanja radikalno razlikuje od današnje kulture postmodernizma. Susrećemo Isusa koji u svome govoru zna biti nepristojan, grub, neposredan i bez poštovanja. Isus je zbog toga često izazivao negativne reakcije. Njegovo je učenje oštro i striktno, a u njemu nema puno prostora za neizmjernu milost i dobrotu prema nevaljalima.

Da bismo dokazali takvu sliku o Isusu, promotrit ćemo sljedeće dijelove teksta sinoptičkih evanđelja: a) sva mjesta gdje Isus govori o ljubavi; b) sva mjesta gdje se Isus koristi grubim riječima; c) sva mjesta gdje Isus upotrebljava metodu oštre poduke i d) sva mjesta gdje Isus svojim govorom, ponašanjem ili učenjem izaziva negativne reakcije. Svrha je ovoga istraživanja utvrditi pravu sliku Isusa iz sinoptičkih evanđelja te je usporediti sa slikom Isusa koja proizlazi iz suvremene kulture, oblikovane postmodernizmom i političkom korektnošću - da navedemo samo dvije od relevantnih odrednica koje oblikuju suvremenu zapadnu kulturu. Nadamo se da ćemo moći uvidjeti očitu razliku između Isusa, kakav je opisan u sinoptičkim evanđeljima, i Isusa postmodernoga doba te da ćemo odatle izvući neke valjane zaključke koji će nam pomoći u oblikovanju svoga ponašanja.

\section{Isusov govor o ljubavi}

Iznenadit će nas činjenica da Isus u sinoptičkim evanđeljima nije puno govorio o temi ljubavi. Ako izuzmemo Ivanovo evanđelje, opažamo sljedeće: Božja ljubav za ljude zapravo se u sinoptičkim evanđeljima gotovo i ne spominje. Osim na dva mjesta (Mt 5,43-46; Lk 6,27-35), na kojima se neizravno govori o Božjoj ljubavi prema ljudima, u većini slučajeva gdje se spominje ljubav, zapravo se govori o ljudskoj ljubavi prema Bogu (Mt 6,24; 22,37; Mk 12,30, 33; Lk 7,42-47; 10,27; 16,13). U dijelu teksta koji se nalazi vrlo blizu, sinoptička evanđelja govore o ljubavi prema bližnjem ili neprijatelju (Mt 5,33-46; 19,19; 22,39; Mk 12,31, 33; Lk 6,27-35). U jednom je slučaju Isus osjetio ljubav prema jednoj osobi (Mk 10,21), jedan je rimski vojnik opisan kao netko tko voli židovski narod (Lk 7,5), a u 
jednoj situaciji ljubav ima negativnu konotaciju jer se opisuje grešna ljubav za javnim počastima (Lk 11,43).

\section{Isusov oštar izričaj}

Sinoptička evanđelja otkrivaju potencijalno neugodnu sliku Isusova stila govora pošto vidimo Isusa koji se koristi toliko oštrim jezikom da bi takav izričaj danas bio sasvim neprikladan i u najmanju ruku označen kao "govor mržnje“. Identificirat ćemo svaki od tih izraza i njihove ciljne skupine.

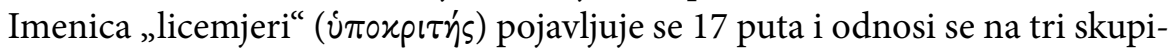
ne: kao prvo, Isus najčešće definira farizeje, a ponekad i saduceje, kao licemjere (Mt 15,7; 22,18; 23,13, 15, 23, 25, 27, 28, 29; Mk 7,6; Lk 13,15); a kao drugo, Isus govori općenito o licemjerima (Mt 6,2, 5, 16; 7,5; Lk 6,42). Ono što u tim slučajevima ljude čini licemjerima njihovo je osobito ponašanje ili postupci. Kao treće, Isus obilježava mnoštvo kao licemjere (Lk 12,56).

Pridjev „slijep“ ( $\tau \cup \phi \lambda o ́ s)$ pojavljuje se 9 puta u tekstovima sinoptičkih evanđelja. Na šest mjesta odnosi se na farizeje, a ponekad na pismoznance (Mt 15,14; $23,16,17,19,24,26)$, jednom se odnosi na one koji slijede farizeje (Mt 15,14), a jednom na ljude općenito (Lk 6,39).

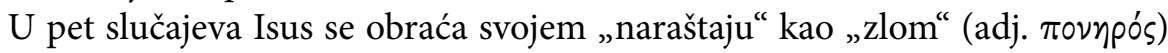

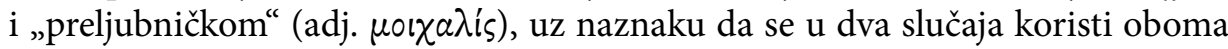
izrazima (Mt 12,39; 16,4). U dva slučaja (Mt 12,45; Lk 11,29) koristi se samo izrazom „zao“ (adj. Tovnpós), a u Mk 8,38 Isus opisuje svoj naraštaj kao „preljubnički“

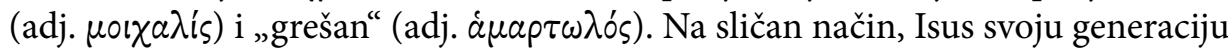

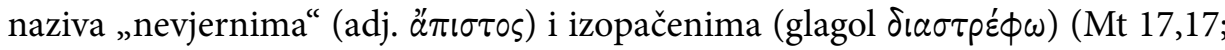
Lk 9,41), ali u Mk 9,19 koristi samo pridjev „nevjerni“ (ä $\pi\llcorner\sigma \tau \circ \varsigma)$. Nadalje, Isus u dva navrata ne koristi nikakve posebne riječi kako bi opisao ljude svoga naraštaja, već kroz parabolično učenje otkriva da nikad nisu zadovoljni s Božjim poslanicima (Mt 11,16-19; Lk 11,31-35).

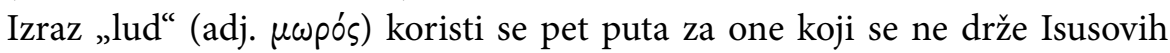
riječi (Mt 7,26), jednom se koristi za opis farizeja i pismoznanaca (Mt 23,17), a tri puta u prispodobi o deset djevica (Mt 25,2,3,8). Na isti način Isus se pet puta koristi riječju „Zao“ (adj. Tounpós): jednom u općem smislu (Mt 7,11); jednom naziva svoje učenike „zlima“ (Lk 11,13), dvaput tako naziva pismoznance (Mt 9,4; 12,34), a jednom farizeje ( $\operatorname{Lk} 11,39)$.

Izraz „vukovi“ ( $\lambda$ úxos) koristi se tri puta: jednom za lažne proroke (Mt 7,15), a dva puta za ljude općenito (Mt 10,16; Lk 10,3). Također, izrazom „razbojnici“ $(\lambda \eta \sigma \tau \dot{\eta}$ s) koristi se tri puta, a svaki se put odnosi na trgovce u Hramu (Mt 21,13; Mk 11,17; Lk 19,46).

Isus dva puta koristi riječ „mali psi“ (xuvápıov) za jednu ženu poganku (Mt 
15,26-27; Mk 7,27-28), ali neizravno tako naziva sve poganske narode. Isto tako, Isus dva puta ljude naziva ,slijepi i gluhi“ (Mt 13,13; Mk 4,11-12). Iako te riječi ne upotrebljava doslovno, njegov opis ljudi kao onih koji „gledajući ne vide i slušajući ne čuju" nedvojbeno ima taj smisao. Također, dva se puta upotrebljava izraz „zmijski porod“ ( $\gamma \varepsilon \nu \nu \eta ́ \mu \alpha \tau \alpha ~ \varepsilon ̇ \chi ı \delta \nu \tilde{\omega} \nu)$ (Mt 12,34; 23,33) za farizeje (i pismoznance u Mt 23,33). ${ }^{1}$ Dva puta (Mt 23,31; Lk 11,47-48) Isus opisuje farizeje i pismoznance kao „sinove očeva koji su ubijali proroke“, a što se odnosi na njihovo dioništvo $\mathrm{u}$ istoj krivnji kakvu nose njihovi očevi. Dva puta (Mt 23,25; Lk 11,39) Isus optu-

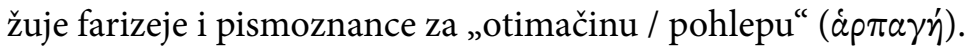

Izraz „Zmija“ (ő $\phi \varsigma)$ koristi se jedan put (Mt 23,33) kao pogrdni opis farizeja i pismoznanaca. Jednom prigodom Isus naziva neidentificirane osobe kao "pse“

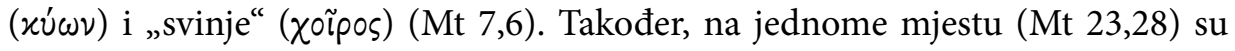

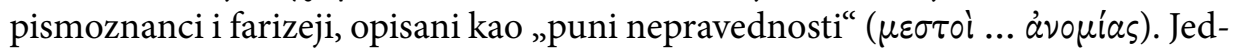

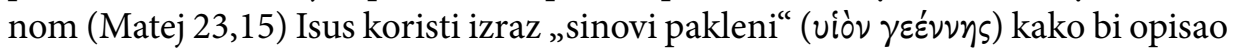
farizeje i pismoznance. U Mt 23,27 Isus naziva farizeje i pismoznance „okrečenim

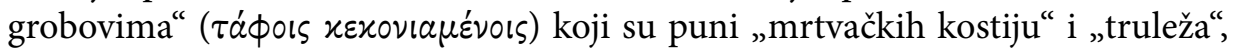
dok ih u Lk 11,44 opisuje kao "neoznačene grobove“ ( $\mu \nu \eta \mu \varepsilon i \alpha ~ \tau \dot{\alpha} a ̈ d \eta \lambda \lambda \alpha$ ), a u Mt 23,25 opisuje farizeje i pismoznance kao åkpaбía, što doslovno znači „bez snage", odnosno da ne vladaju sobom, a to se očituje u njihovu samodopadnom stilu života.

\section{Isusov oštar nauk}

Budući da Isus nije bio izrazito ugodan sugovornik, tako i njegovo učenje odražava tu notu grubosti i ozbiljnosti. U ovom ćemo odlomku analizirati Isusov oštar nauk, koji je djelomično prisutan u njegovom jeziku, kao što smo to vidjeli u prethodnom odlomku, ali također i u sadržaju njegova učenja. Svrha nije ovdje sažeti sve što je Isus podučavao, već ponuditi djelomični prikaz njegova učenja koji će, nadamo se, biti dovoljan kako bi se uvidjela grubost i ozbiljnost njegova nauka.

U Mt 7,19 i Lk 6,44 Isus govori o tome da se „svako stablo koje ne rađa dobrim rodom, siječe i baca u oganj“, dok će u Mt 7,21-23 Isus uskratiti ulazak u svoje kraljevstvo svakome tko ne vrši volju njegova Oca. Tu su uključeni oni koji prorokuju, liječe bolesne i istjeruju zle duhove - sve što je Isus obećao svojim učenicima da će i oni činiti. No glavni problem s ovom skupinom ljudi je da oni, unatoč svom karizmatičnom daru, krše Zakon - a to čine oni koji potiču bezako-

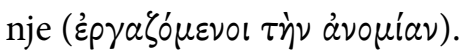

U Mt 8,11-12 Isus nastavlja ovu vrstu govora, rekavši da će „sinovi kraljevstva 
biti bačeni u krajnju tamu“. Slično tomu, u Lk 13,25-30 Isus govori o onima koji su ,jeli i pili s njim“, ali će ipak biti izbačeni iz kraljevstva.

U Mt 10,14-15 Isus izravno govori o sudbini onih koji odbacuju svjedočanstvo učenika: „Ako vas gdje ne prime, ili ne poslušaju vaših riječi, iziđite iz te kuće ili grada i otresite prah sa svojih nogu. Zaista, kažem vam, na Sudnji dan lakše će biti Sodomi i Gomori nego onom gradu." U Mk 6,7-12; Lk 9,5 i Lk 10,10 Isus još izravnije upućuje svoje učenike da, ako njihovo svjedočanstvo ne bude prihvaćeno, trebaju napustiti to mjesto i otresti prašinu sa svojih nogu kao svjedočanstvo protiv tamošnjih ljudi.

U Mt 12,25-37 i Mk 3,22-30 Isus govori o bogohuljenju protiv Duha kao neoprostivom grijehu, a u Mt 18,6-9; Mk 9,42-50 i Lk 17,1-2 protiv ljudi koji uzrokuju da „jedan od ovih malenih - što u me vjeruju“ posrnu. Za takve ljude „bilo bi bolje da im objese o vrat mlinski kamen i da se utope u morskim dubinama“. Iako je točna narav „malenih“ upitna, ipak će sudbina onih koji su ih naveli na grijeh biti teška.

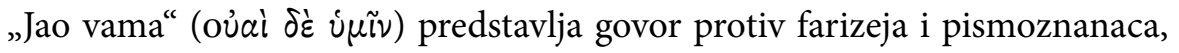
koji se pojavljuje u Mt 23,1-36; Lk 11,37-54; dok se u Lk 24-26 ,jao vama“ odnosi na bogataše koji imaju pun trbuh, koji se smiju i hvaljeni su od naroda.

U Mt 12,30 i Lk 11,23 Isus je jasan kad kaže da je onaj koji nije za njega i koji ne skuplja s njim, protiv njega i da rasipa. Tu ne postoji „između“, već samo „iliili“.

Iako je Isus "princ mira“, u Lk 12,49-53 objavljuje da nije došao donijeti mir na zemlju, već razdor, a u Lk 13,1-5 Isus se koristi primjerima ljudi koje je Pilat ubio te kaže da su poginuli kada je kula u Siloi pala na njih i time objašnjava mnoštvu da su grešni baš kao i ti ljudi, i da će također izginuti ako se ne pokaju.

U Mt 7,14 i Lk 13,24 Isus govori o „uskim vratima“ i „tijesnom putu koji vodi u život“. Nasuprot tomu, često je govorio o „paklu“ ( $\gamma \varepsilon \dot{\varepsilon} \varepsilon \nu \alpha)$ : Mt 5,22, 29-30; 10,$28 ; 18,9 ; 23,15,33 ; \mathrm{Mk} 9,43,45,47$; Lk 12,5; a ponekad je upotrebljavao sinonime za pakao kao što su: „ognjena peć ... mjesto gdje će biti plač i škrgut zuba“ (Mt 13,42, 50), „oganj vječni“ (Mt 25,41), „muka vječna“ (Mt 25,46).

Sljedeća četiri primjera, koja su preuzeta iz prispodoba, također otkrivaju oštrinu njegova nauka: a) u prispodobi o nemilosrdnom dužniku u Mt 18,34-35 Isus kaže da, ako ne oprostimo kada se to od nas traži, bit ćemo predani mučiteljima; b) u prispodobi o svadbenoj gozbi u Mt 22,12-13 oni koji nemaju svadbeno ruho bit će bačeni u tamu; c) u Lk 19,27 u prispodobi o novčićima Isus kaže: „A moje neprijatelje, koji nisu htjeli da zavladam nad njima, dovedite ovamo i pogubite ih preda mnom!" te, konačno, d) govoreći o nepoznatom danu i satu svoga dolaska u Mt 24,51, Isus kaže da će nevjerni i zli sluga biti strogo kažnjen te da će mu se dodijeliti mjesto na kojem će ispaštati kaznu zajedno s licemjerima.

$\mathrm{Na}$ posljetku, razmotrimo načine na koje Isus tretira odabrane skupine ljudi. 
Prvo, u razgovorima u kojima je njegov identitet doveden u pitanje i osporavan, posramljuje svoje protivnike, ušutkujući ih i tako zadobivajući svoju čast (Mt 22,22, 34, 46; Mk 12,12, 13-34; Lk 13,17; 14,1-6; 20,20-39).

Drugo, ponekad kori svoje učenike: u Mk 8,17-19 ih pita jesu li njihova srca tvrda, oči slijepe, a uši zatvorene jer ne razumiju ono što im pokušava reći. Sličan se način govora pojavljuje na kraju Markova evanđelja $(16,14)$, kad Isus kori svoje učenike zbog njihove "nevjere i okorjelosti srca“. Isti smisao ima i Isusov govor

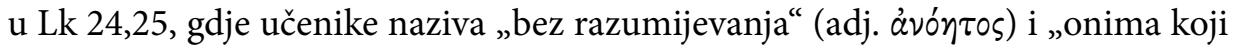
presporo vjeruju svemu što su proroci govorili!" U Lk 11,13 Isus ih čak naziva „zlima“ - „Dakle: ako vi, premda ste zli, možete davati svojoj djeci dobre darove..."

Treće, Isus proklinje različite skupine ljudi i mjesta: a) svoj naraštaj (Mt 11,16-19; 12,41-45; 23,33-36; Mk 9,19; Lk 11,49-51; b) farizeje i pismoznance (Mt 15,13; 23,1-36; Mk 12,38-40; Lk 11,37-54; 20,45-47; c) razne gradove (Mt 10,14-15; 11,20-24; Mk 6,11; Lk 9,5; 10,10-12; 10,13-15), a posebice Jeruzalem (Mt 23,37-39; Lk 13,34-35; 19,41-44); d) Hram (Mt 24,1-2; Mk 13,1-2; Lk 21,5-6) i trgovce u Hramu (Mt 21,12-16; Mk 11,15-18; Lk 19,45-46).

\section{Reakcija na Isusove riječi, nauk i djela}

Do sada smo identificirali neka mjesta gdje je Isus u svojim riječima, učenjima i ponašanju pokazao vrlo oštar nauk. Možemo zaključiti da nije bio ugodan i „za uši blag" učitelj / propovjednik. Zato je i reakcija drugih često bila intenzivna. Iako ga je narod hvalio, njegov oštar i grub izričaj i ponašanje donijeli su mu rastući broj neprijatelja, što ga je na kraju stajalo i života. Stoga, identificirat ćemo negativne reakcije koje je Isus doživio tijekom svoje službe:

- $\quad$ traže ga da napusti njihov kraj: Mt 8,28-34; Mk 5,1-17; Lk 8,26-37

- smatraju da bogohuli: Mt 9,3-4; Lk 5,21-26

- smiju mu se: Mt 9,24-25; Mk 5,40

- planiraju ga uloviti i ubiti: Mt 12,14; Mk 12,12; Lk 4,22-30; 13,31-33; 19,45-47; 20,19-20

- $\quad$ dovode ga u vezu s Belzebulom: Mt 10,25; 12,24-27; Mk 3,22; Lk 11,1519

- ljute se na njega: Mt 21,16; 21,46; Lk 6,7-11; 11,37-54; 13,14-17

- Isus kao prorok ne uživa čast u vlastitu gradu: Mt 13,57; Mk 6,4; Lk 4,24

- izruguju se njegovu učenju: Lk 16,14-16

- suprotstavljaju se njegovu učenju i ponašanju: $M k$ 2,6, 16, 24

- misle da je lud: Mk 3,21

- testiraju ga, postavljajući mu pitanja: Mt 16,1; 19,3; 22,35; Mk 8,11; 
10,2; Lk 10,25; 11,16

- $\quad$ ljudi se bune zbog Isusa: Mt 9,11; Lk 5,30-32; 15,2; 19,7

- on je za njih sablazan: Mt 13,57; 15,12; Mk 6,3

- ljudi osjećaju da ih Isus vrijeđa: Lk 11,45

- traže razlog da ga optuže: Mt 12,10; Mk 3,2, Lk 6,7; ili da ga na sličan način uhvate u zamku njegovih vlastitih riječi: Mt 22,15; Mk 12,13

- pažljivo ga prate: Lk 14,1; Lk 20,20

- izruguju mu se, muče ga i ubijaju: Mt 26,67-68; 27,27-38, 39-44; Mk 14,$65 ; 15,29-32$; Lk 22,63; 23,34-37

Židovske su vlasti osudile Isusa, kao onoga koji huli Boga (religijska optužba), a rimske su ga vlasti pogubile sramotnom smrću raspeća pod optužbom „kralj Židova“, što ga je označilo kao kriminalca i pobunjenika protiv samoga Rima (pravna optužba). Poanta je u tome da je Isus tijekom svoje službe bio u stalnom sukobu sa židovskim vjerskim vlastima, ali također i sa svojim naraštajem. Mnogi su ga slavili i slijedili, ali s vremenom je imao sve više protivnika, a njegovi su ga postupci i riječi na kraju odveli na križ.

\section{Isus današnjice}

Ako pogledamo današnju zapadnu kulturu, možemo prepoznati dva čimbenika koja imaju vrlo snažan utjecaj: postmodernizam i njegovog potomka „političku korektnost“. Ne želimo definirati postmodernizam, i što bi u kontekstu ovoga članka bio veoma težak zadatak, pa ćemo ga radije opisati. Prema Christopheru Norrisu, postmodernizam ima tri ključna aspekta: epistemologiju, etiku i estetiku. Epistemološki postmodernizam temelji se na postavci skepticizma o mogućnosti spoznaje i istine, kao i mogućnosti konstruktivnog, zajedničkog stremljenja prema istini koja stoji na završetku takve potrage $(2000,57)$. Ako već nije moguće definirati istinu ili konačnu istinu, postmodernizam prirodno tvrdi da različiti ljudi imaju različite sustave uvjerenja, vrijednosti, ideja i sl., koji su jednako vrijedni i dobri. Dakle, nismo u stanju suditi između dobra i zla. Kao posljedica toga, trebamo poštovati mišljenja drugih, a da im ne pokušavamo nametnuti svoju verziju istine. Premda ovakav pristup izgleda kao da zaslužuje puno poštovanje i čast, ako takve postavke pokušamo slijediti do njihovih konačnih zaključaka, one će nas dovesti do monolitnog i amorfnog društva u kojem je onemogućena bilo kakva smislena komunikacija i odnos. Ako su sva uvjerenja, vrijednosti i ideje, bilo da pripadaju pojedincu ili određenoj društvenoj skupini, jednako dobri i pozitivni, a ne postoji način njihova procjenjivanja ili prosuđivanja, na putu smo prema disfunkcionalnom društvu.

Prema Geoffreyju Hughesu (2009, 3), pojam „politička korektnost“ postao je 
dio modernog jezika kao posljedica široke javne rasprave koja je počela krajem 1980-ih godina na sveučilišnim kampusima u SAD-u. Isprva je pojam bio povezan s obrazovanjem i nastavnim programom na američkim kampusima, no danas se koristi u mnogim različitim područjima života, kao što su, primjerice, politika, književnost, obrazovanje, spolnost, kultura i obrasci ponašanja. Bez pokušaja opsežnog definiranja, ${ }^{2}$ možemo reći da "politička korektnost nameće osjećaj obveze ili usklađenosti na područjima koja bi trebala biti (ili jesu) stvar izbora. Ipak, imala je značajan utjecaj na oblikovanje onoga što se smatra 'prihvatljivim' ili 'prikladnim' u smislu jezika, ideja, oblika ponašanja i sustava vrijednosti“ (Hughes 2009,4$)$. Hughes $(2009,38)$ objašnjava kako se politička korektnost u osnovi bavi promjenom oblika ponašanja i jezika, nastojeći naglasiti ljudsku društvenost $\mathrm{i}$ umanjiti usvojene razlike i isključivosti, obeshrabrujući pritom prosudbene stavove i zabranjujući jezik koji netko može smatrati uvredljivim. Istodobno se uspostavljaju novi okviri vrijednosti i morala, koji u određenoj mjeri zamjenjuju tradicionalne ortodoksne kategorije (usp. Hughes 2009, 58-59).

No još je važnije kako ovaj koncept utječe na svakodnevni jezik ili govor. Hughes $(2009,14)$ objašnjava kako je „uobičajeno da jezik političke korektnosti izbjegava osuđujuće izraze, preferirajući umjetno stvorenu monetu višesložnih apstraktnih eufemističkih supstitucija." Također, eufemizmi se koriste zato što je „politička korektnost sklona izbjegavati izravno upućivanje na neku neugodnu temu ili stanje" (Hughes 2009, 18). Međutim, kao što je Otto Jespersen (1912, 243) uočio: „To je uobičajena sudbina eufemizama; kako bi izbjegli pravi naziv za ono što se smatra nepristojnim ili neprimjerenim, ljudi koriste neku nevinu riječ. Ali kada to u tom smislu postane uobičajeno, tada nova riječ postane jednako neugodna kao i ona prethodna, te se također odbacuje."

Ova nam uvodna analiza pomaže da uvidimo kako samo ta dva čimbenika (naravno da postoje i drugi čimbenici koji oblikuju suvremenu zapadnu kulturu) izrazito oblikuju našu zapadnu kulturu - kulturu u kojoj živi kršćanska Crkva. Pa

2 Prema Hughesu $(2009,17)$, problem je definirati pojam „politička korektnost“ jer su definicije često problematične ili neprimjerene: „To se dešava stoga što je formula političke korektnosti inherentno problematična semantička konstrukcija. Na prvome mjestu, ne postoji ,ispravni politički stav“, i to iz nekoliko različitih razloga. Politika je po bilo kojoj definiciji raznovrsni pojam koji obuhvaća širok spektar aktivnosti koje prelaze granice državnih poslova i uključuju lokalnu politiku, politiku državnih ureda, obiteljsku politiku, bračnu politiku, seksualnu politiku, politiku identiteta i tako dalje. Nalazimo se gotovo u području marksističke interpretacije koja u svemu vidi politiku. Nadalje, izvan granica totalitarnih društava, ni jedan od političkih sustava ili stranaka ne može tvrditi da je „,korektan“. Čak i unutar glavnih političkih stranaka, postoje „umjereni“, „tvrdolinijski“ i „ekstremisti“. Korektnost, nasuprot tomu, upućuje na usklađenost s pojedinim općeprihvaćenim standardima ili postupcima. Slijedom toga, politička korektnost nema općeusvojeno, jasno doslovno značenje, na način kao što to ima, primjerice, gramatička korektnost ili politička korupcija.“ 
zar onda iznenađuje da ta dominantna kultura oblikuje i preoblikuje kršćansku Crkvu i njezinu teologiju? Kršćanstvo je rezultat Božje objave, a kao posljedica toga, ima sustav vjerovanja koji sadržava apsolutne istine temeljem kojih možemo reći da je nešto pogrešno i loše, ili ispravno i dobro. Ono što je pogrešno i loše Biblija često označava kao "grijeh“ ili „bezakonje“, a ono što je ispravno i dobro označava se kao „svetost“ $i$ „pravednost“. Prema tomu, kršćanstvo ima sustav vjerovanja, ponašanja, odnosa, standarda, vrijednosti i postupaka koji su rezultat Božje objave i kao takvi se ne mogu propitivati.

Nažalost, moderna zapadna kultura sve više oblikuje i preoblikuje tradicionalno evanđeosko kršćanstvo u nešto što postaje gotovo neprepoznatljivo. Ova se promjena može najlakše uočiti u mijenjanju kršćanske „terminologije“, nakon čega slijede daljnje promjene u doktrinama. Pogledajmo neke primjere koji to dokazuju:

(1) Koliko lokalne crkve, denominacije ili poznati učitelji Biblije govore o „istini“, a koliko o „ljubavi“? Kad bi se o tome provelo opsežno istraživanje, nema sumnje da bi ono pokazalo padajući trend govorenja o „istini“ i rastući trend govorenja o „ljubavi“. Ono što je pritom problematično jest da Božja ljubav nije lišena Božje istine. Drugim riječima, ne možemo imati Božju ljubav bez Božje istine.

(2) A što je s „grijehom“? Koliko lokalnih crkava, denominacija ili poznatih učitelja Biblije govori o "ljudskoj grešnosti“ i ,zlom ljudskom srcu“? Sve se manje govori da ljudi „žive u grijehu“, a sve više da „nisu savršeni“. Stoga, imamo slogan „Kršćani nisu savršeni, samo im je oprošteno“. Mijenjajući naljepnicu, nužno mijenjamo i sve drugo. Život u grijehu zahtijeva pokajanje, a ako kažemo da nismo savršeni, znači da naša situacija i nije baš toliko strašna. Na kraju, možda samo trebamo pomoć - i to je to.

(3) Nastavljajući se na prethodnu misao, u današnjoj je kulturi sve teže nazvati grijeh pravim imenom i označiti grešnoga čovjeka kao „grešnika“. To jednostavno nije politički korektno. Stoga, Kevin A. Thompson (2003) piše:

Ti si grešnik. Žao mi je što ti to moram reći. Znam da to nije politički korektno, ali je istina. Mnoge tvoje misli, postupci i djela ne služe na slavu Bogu. To se također odnosi i na mnoga moja djela. Istina od nas zahtijeva da stvari nazivamo njihovim pravim imenom. Ti i ja smo grešnici. Možemo živjeti u poricanju ove činjenice. Možemo se pretvarati da je sve u redu. Možemo stvoriti politički korektan svijet u kojemu nikada ne govorimo istinu. Ali to neće promijeniti istinu - mi smo grješnici.

Thompson želi reći da je u današnjoj zapadnoj kulturi, koja izbjegava korištenje osuđujućih pojmova uz pomoć eufemizama, kršćanska terminologija, što proizlazi iz Božjih apsoluta, u najmanju ruku nepoželjna.

(4) Govoreći na temu osuđivanja drugih, Thomas L. Carson (1988) kaže: 
Ljudi ne kažu “Tko sam JA da sudim?” već “Tko smo MI(VI) da sudimo / sudite?” ili “Tko je ON / ONA (BILO TKO) da sudi?” Pitanje se obično postavlja kao osuda ili izraz neodobravanja onih koji donose moralne prosudbe i obično služi tome da prenese poruku da su oni koji moralno prosuđuju krivi za neku vrstu arogancije ili predrasude. Pitanje „Tko smo mi da sudimo?“ često pretpostavlja izražavanje moralnog skepticizma. Ne trebamo osuđivati jer nismo sposobni dostići znanje o moralnim pitanjima ... S druge strane, neki od onih koji pitaju „Tko smo mi da sudimo?“ skloniji su etičkom relativizmu ili meta-etičkom relativizmu, prema kojem moralne prosudbe nisu objektivno istina ili laž, već su u najboljem slučaju istinite ili točne $z a$ odabranog pojedinca.

Možemo li zaista iskreno reći da, iako znamo Božje apsolutne istine, ${ }^{3}$ ne možemo prosuđivati jer za to nemamo dovoljno znanja? Ili da možemo odobriti etički relativizam? Zasigurno ne. I još je apsurdnije da oni koji postavljaju takva pitanja, koji zabranjuju prosuđivanje drugih, u stvarnosti upravo to i rade - prosuđuju druge.

$\mathrm{Na}$ temelju prethodnih primjera možemo vidjeti da određene doktrinarne pretpostavke ili uvjerenja mijenjaju način na koji govorimo i kako se odnosimo prema određenim pojavama. Slijedom toga i preostale se doktrine također mijenjaju kako bi se uskladile s novim doktrinarnim uvjerenjima. No budući da kršćani drže do određenih uvjerenja, sukob između kršćanstva i kulture je neizbježan. U tome smislu Ruth Meyer kaže: „Politički je nekorektno reći da je Isus jedini put u nebo. Za one koji se usude to ustvrditi kaže se da su 'netolerantni' i 'bez ljubavi'. Ako se usudimo zauzeti određeno stajalište o nekom moralnom ili društvenom pitanju, kao što je Phil Robertson učinio protiv homoseksualnosti, pokrećemo vatrenu oluju i postajemo 'mrzitelji.' Zato su mnogi kršćani zaključili da im je najlakše ne reći ništa." Međutim, problem za kršćanstvo ne završava ovdje. Ne samo što smo često označeni kao mrzitelji, netolerantni i slično, već se i pojam „kršćanin“ povezuje s mnogim nekršćanskim stvarima. Pa tako imamo „kršćansku jogu“, „kršćanske homoseksualce“, „kršćanske sanjarice“ pa čak i „kršćanske swingere“. Drugim riječima, imamo konkurentne verzije kršćanstva, od kojih svaka tvrdi da slijedi učenje i primjer Isusa Krista.

3 “Živimo u svijetu koji sve više nastoji (navodno) promicati ideju tolerancije, ali zapravo postaje netolerantan prema kršćanskim apsolutnim istinama. Bilo da se radi o religiji, ponašanju ili ljudskoj spolnosti, u Americi i drugim zapadnim zemljama sve više raste antikršćanski stav. $\mathrm{Na}$ posljetku, u takvu „toleranciju“ ugrađen je i koncept da istinu određuje pojedinac, a ne Bog. To je dovelo mnoge ljude do zaključka da je prosuđivanje o bilo kome (pogotovo kršćana) pogrešno jer Biblija kaže „ne sudite“ (Mt 7,1). No zanimljivo je da oni koji odbacuju pojam Boga ili vjerodostojnost Biblije često pokušavaju koristiti Božju riječ (npr. citirajući biblijske retke izvan konteksta) kako bi opravdali svoje postupke koji se, međutim, u evanđeljima osuđuju i odbacuju“ (Ham, Ham \& Chakranarayan 2013). 


\section{Zaključak}

Ako prihvatimo postmodernističkog - politički korektnog - sveljubećeg - nevrijeđajućeg - otvoreno razmišljajućeg - neprosuđujućeg - sveprihvaćajućeg Isusa 21. stoljeća, kao istinskoga biblijskog Isusa, suočavamo se s dva radikalno različita Isusa. Pred nama je izbor: hoćemo li slijediti Isusa Evanđelja ili Isusa današnjice. Treba imati na umu da je ovakav izbor rezultat jednog procesa koji se događa u pozadini i koji je star koliko i stvaranje: kada je Bog stvorio čovjeka, stvorio ga je na svoju sliku. Pad je bio rezultat djelovanja čovjeka koji je želio biti poput Boga. Prema tomu, kroz cijelu ljudsku povijest, ljudi pokušavaju stvoriti Boga na svoju sliku, no biblijski je Bog u procesu ponovnog stvaranja ljudi na svoju sliku.

Augustin je rekao: „Ako vjerujete u ono što volite u evanđeljima i odbacujete ono što vam se ne sviđa, onda ne vjerujete u evanđelje, već u sebe.“ Vidjeli smo da u sinoptičkim evanđeljima Isus relativno rijetko govori o ljubavi. Kada govori o ljubavi, tada prije svega naglašava potrebu da ljudi vole Boga. Isus, dakle, nije puno govorio o tome kako Bog voli ljude.

Također, vidjeli smo da je Isus u svome učenju i govoru znao biti vrlo uvredljiv. Jasno je identificirao ljudske grijehe, a pojedine ljude, pa čak i čitav naraštaj, nazivao je imenima koja su opisivala njihovo duhovno stanje („budale“, „licemjeri“, „slijepci“ itd.). Zato što je govorio istinu, ljudi su često bili zbog njega uzrujani. Dokaze za to predstavio sam u prvome dijelu ovoga članka.

Da se Isus iz evanđelja na neki način nađe u našem vremenu i ponovi svoju zemaljsku službu, kao što vidimo u sinoptičkim evanđeljima, vjerojatno bi bio označen kao „mrzitelj“, „netrpeljiv“ ili „netolerantan“ prema drugima, „bez ljubavi“, „fobičan“ itd. Vjerojatno bi mnogi, koji nose njegovo ime, bili uvrijeđeni njegovim govorom i ponašanjem te bi mu rekli da se treba pokajati i riješiti svoga uvredljivog stava. Možda bi rekli da mu nedostaje „kršćanske ljubavi“ ili da nije "duhovan“. Ako bi to bio slučaj, onda smo promašili. Isus iz evanđelja nije se promijenio. Isti je jučer, danas i zauvijek, a mi trebamo biti vrlo pažljivi kako ne bismo slijedili nekog „suvremenog Isusa“, već Isusa evanđelja. 


\section{Dodatak}

Tablica 1. Isus govori o ljubavi

\begin{tabular}{|l|l|}
\hline \multicolumn{1}{|c|}{ Sadržaj } & \multicolumn{1}{c|}{ Tekst } \\
\hline Ljubite svoje neprijatelje (zato što ih Bog ljubi). & Mt 5,43-46; Lk 6,27-35 \\
\hline Nitko ne može služiti dvojici gospodara. & Mt 6,24; Lk 16,13 \\
\hline Ljubi svoga bližnjega kao samoga sebe. & $\begin{array}{l}\text { Mt 19,19; Mt 22,39; Mk 12,31; } \\
\text { Mk 12,33 }\end{array}$ \\
\hline $\begin{array}{l}\text { Ljubi Gospodina Boga svoga svim srcem svojim, } \\
\text { svom dušom svojom i svom pameti svojom. }\end{array}$ & $\begin{array}{l}\text { Mt 22,37; Mk 12,30; Mk 12,33; } \\
\text { Lk 10,27 }\end{array}$ \\
\hline ... a to ga Isus pogleda i zavoli ga. & Mk 10,21 \\
\hline Stotnik koji voli židovski narod. & Lk 7,5 \\
\hline Prispodoba o opraštanju i tko voli više. & Lk 7,42-47 \\
\hline Farizeji koji vole prva mjesta i pozdrave. & Lk 11,43 \\
\hline
\end{tabular}

Tablica 2. Isusov oštri govor i učenje

\begin{tabular}{|c|c|}
\hline Licemjeri & $\begin{array}{l}\text { Općenito: Mt 6,2, 5, 16; 7,5; Lk 6,42 } \\
\text { Farizeji: Mt 15;7; 22,18; 23,13, 15, 23, 25, 27, 28, 29; Mk } \\
\text { 7,6; Lk 13,15 } \\
\text { Mnoštvo: Lk 12,56 }\end{array}$ \\
\hline Slijepi & $\begin{array}{l}\text { Farizeji: Mt 15,14; 23,16, 17, 19, 24, } 26 \\
\text { Sljedbenici farizeja: Mt 15,14 } \\
\text { Općenito: Lk 6,39 }\end{array}$ \\
\hline $\begin{array}{l}\text { Pokvareni i preljubnički } \\
\text { naraštaj }\end{array}$ & $\begin{array}{l}\text { Naraštaj: Mt 12,39, } 45 \text { (samo pokvareni); 16,4; Mk 8,38; } \\
\text { Lk 11,29 (samo pokvareni) }\end{array}$ \\
\hline $\begin{array}{l}\text { Nevjerni i pokvareni } \\
\text { naraštaj }\end{array}$ & Mt 17,17; Mk 9,19; Lk 9,41 \\
\hline Nikad zadovoljan naraštaj & Mt 11,16-19; Lk 11,31-35 \\
\hline Lude & $\begin{array}{l}\text { Svatko tko ne sluša Njegove riječi: Mt 7,26; Mt 25,2,3,8 } \\
\text { Farizeji: Mt 23,17 }\end{array}$ \\
\hline Zli & $\begin{array}{l}\text { Općenito: Mt 7,11; Lk 11,13 (govori to svojim učenicima) } \\
\text { Farizeji: Lk 11;39 } \\
\text { Pismoznanci: Mt 9,4; 12,34 }\end{array}$ \\
\hline Vukovi & $\begin{array}{l}\text { Lažni proroci: 7,15 } \\
\text { Ljudi: Mt 10,16; Lk 10,3 }\end{array}$ \\
\hline Kradljivci & Trgovci u Hramu: Mt 21,13; Mk 11,17; Lk 19,46 \\
\hline
\end{tabular}




\begin{tabular}{|c|c|}
\hline Mali psi & Mt 15,26; Mk 7,27 \\
\hline Slijepi i gluhi & Ljudi općenito: Mt 13,13; Mk 4,11-12 \\
\hline Zmijski porod & Farizeji: Mt 12,34; 23,33 \\
\hline Ubojice proroka & Mt 23,29-32; Lk 11,47-48 \\
\hline Otimačina / pohlepa & Farizeji i pismoznanci: Mt 23,25 Lk 11,39 \\
\hline Zmija & Mt 23,33 \\
\hline Psi i svinje & Mt 7,6 \\
\hline Nepravedni & Mt 23,28 \\
\hline Sinovi pakla & Farizeji i pismoznanci: Mt 23,15 \\
\hline $\begin{array}{l}\text { Okrečeni grobovi, } \\
\text { mrtvačke kosti, trulež }\end{array}$ & Mt 23,27 \\
\hline Neoznačeni grobovi & Lk 11,44 \\
\hline Nemoćni & Mt 23,25 \\
\hline $\begin{array}{l}\text { Isus posramljuje svoje } \\
\text { protivnike }\end{array}$ & $\begin{array}{l}\text { Mt 22,22, 34, 46; Mk 12,12, 13-34; Lk 13,17; 14,1-6; } \\
20,20-39\end{array}$ \\
\hline Kori svoje učenike & $\begin{array}{l}\text { Petar Mt 16,23 i Mk 8,31-33; Mk 8,17-19; 16,14; Lk 11,13 } \\
\text { (kaže da su zli); Lk 24,25 }\end{array}$ \\
\hline $\begin{array}{l}\text { Osuda u riječima i } \\
\text { djelima }\end{array}$ & $\begin{array}{l}\text { Naraštaj: Mt 11,16-19; 12,41-45; 23,33-36; Mk 9,19; Lk } \\
\text { 11,49-51 } \\
\text { Farizeji i pismoznanci: Mt 15,13; 23,1-36; Mk 12,38-40; } \\
\text { Lk 11,37-54; 20,45-47 } \\
\text { Gradovi: Mt 10,14-15; 11,20-24; Mk 6,11; Lk 9,5; 10,10- } \\
\text { 12, 13-15 } \\
\text { Hram: Mt 24,1-2; Mk 13,1-2; Lk 21,5-6 } \\
\text { Jeruzalem: Mt 23,37-39; Lk 13,34-35; 19,41-44 } \\
\text { Osuda pismoznanaca zbog njihove pohlepe: Mk 12,38- } \\
\text { 40; Lk 20,47 } \\
\text { Trgovci u Hramu: Mt 21,12-16; Mk 11,15-18; Lk 19,45-46 }\end{array}$ \\
\hline Pakao & $\begin{array}{l}\text { Mt 5,22, 29-30; 10,28; 18,9; 23,15 (sinovi pakla); 23,33; } \\
\text { Mk 9,43;9,45; 9,47; Lk 12,5 }\end{array}$ \\
\hline Sinonimi za pakao & Mt $13,42,50 ; 25,41$ \\
\hline
\end{tabular}




\section{Tablica 3. Negativne reakcije na Isusa}

\begin{tabular}{|c|c|}
\hline Traže da napusti njihov kraj & Mt 8,28-34; Mk 5,1-17; Lk 8,26-37 \\
\hline Optužuju ga za bogohuljenje & Mt 9,3-4; Lk 5,21-26 \\
\hline Smiju mu se & Mt 9,24-25; Mk 5,40 \\
\hline Planiraju ga uloviti i ubiti & $\begin{array}{l}\text { Mt 12,14; Mk 12,12; Lk 4,22-30; Lk 13,31-33; } \\
19,45-47 ; 20,19-20\end{array}$ \\
\hline Povezuju ga s Belzebulom & Mt 10,25; 12,24-27; Mk 3,22; Lk 11,15-19 \\
\hline Ljute se na njega & Mt 21,16;21,46; Lk 6,7-11; 11,37-54; 13,14-17 \\
\hline $\begin{array}{l}\text { Isus kao prorok ne uživa čast u svom } \\
\text { vlastitom gradu }\end{array}$ & Mt 13,57; Mk 6,4; Lk 4,24 \\
\hline Izruguju se njegovu učenju & Lk 16,14-16 \\
\hline $\begin{array}{l}\text { Suprotstavljaju se njegovu učenju i } \\
\text { ponašanju }\end{array}$ & $\operatorname{Mk} 2,6,16,24$ \\
\hline Misle da je lud & Mk 3,21 \\
\hline Testiraju ga postavljajući mu pitanja & $\begin{array}{l}\text { Mt } 16,1 ; 19,3 ; 22,35 ; \text { Mk 8,11; 10,2; Lk 10,25; } \\
11,16\end{array}$ \\
\hline Ljudi se bune & Mt 9,11; Lk 5,30-32;15,2;19,7 \\
\hline On je za njih sablazan & Mt 13,57; 15,12; Mk 6,3 \\
\hline Ljudi osjećaju da ih Isus vrijeđa & Lk 11,45 \\
\hline $\begin{array}{l}\text { Traže razlog da ga optuže / uhvate u } \\
\text { zamku njegovih vlastitih riječi }\end{array}$ & Mt 12,10; Mk 3,2; Lk 6,7 / Mt 22,15; Mk 12,13 \\
\hline Pažljivo ga prate & Lk 14,1; Lk 20,20 \\
\hline Izruguju mu se, muče ga i ubijaju & $\begin{array}{l}\text { Mt 26,67-68; 27,27-38; 27,39-44; Mk 14,65; } \\
\text { 15,29-32; Lk 22,63; 23,34-37 }\end{array}$ \\
\hline
\end{tabular}

\section{Literatura}

Carson, Thomas L. 1988. Who are we to judge? Teaching Philosophy 11:1 (ožujak): 3-14.

Ham, Ken, Jeremy Ham, and David Chakranarayan. (2013. 26.4.). "Does the Bible Tell Christians to Judge Not?” https://answersingenesis.org/biblequestions/does-the-bible-tell-christians-to-judge-not/ (pristupljeno 10. listopada 2017.).

Hughes, Geoffrey. 2009. Political Correctness: A History of Semantics and Culture 20 Wiley-Blackwell; Chichester \& Malden: Wiley-Blackwell. 
Jespersen, Otto. 1912. Growth and Structure of the English Language. Leipzig: B. G. Teubner.

Meyer, Ruth. (2014, 5.5.). "Politically Correct Christianity." https://truthnotes. net/2014/05/05/politically-correct-christianity/ (pristupljeno 10. listopada 2017.).

Norris, Christopher. 2000. Deconstruction: modern or postmodern?, in: Manuel Barbeito (ed.), Modernity, Modernism, Postmodernism, 45-92. Santiago de Compostela: Universidade de Santiago de Compostela.

Thompson. Kevin A. $(2013,19.12$.) "What I mean when I say 'You are a sinner." http://www.kevinathompson.com/sinner/ (pristupljeno 10. listopada 2017.).

Ervin Budiselić

\title{
Jesus of the Gospels, and Jesus of today
}

\begin{abstract}
Starting from the contemporary dominant values of tolerance, dialogue and political correctness, this article analyses Jesus' speech and teachings in the synoptic gospels in the light of these values. First, the article analyses Jesus' speech about love, and then the focus is on Jesus' harsh language and teaching. After that the article analyses reactions of different people and groups on his language and teaching. Based on this analysis, in the final section the article compares Jesus' of the gospels with distorted portray of Jesus that is sometimes present in contemporary Christianity. The conclusion that is made is that contemporary Western culture has distorted the image of Jesus from the gospels, and has created a modern Jesus which in his speech and teachings reflects today's dominant values. However, Jesus is the same yesterday, today and forever, and we should be very careful to follow not some "contemporary Jesus", but Jesus of the gospels.
\end{abstract}

Key words: Jesus of the Gospels, contemporary Jesus, postmodernism, political correctness, God's love, sin, harsh language and teachings 
